\title{
Monetary Transmission of Global Imbalances in Asian Countries
}

\author{
Woon Gyu Choi and Il Houng Lee
}




\title{
IMF Working Paper
}

Asia and Pacific Department and IMF Institute

\section{Monetary Transmission of Global Imbalances in Asian Countries}

\author{
Prepared by Woon Gyu Choi and Il Houng Lee ${ }^{1}$
}

September 2010

\begin{abstract}
This Working Paper should not be reported as representing the views of the IMF. The views expressed in this Working Paper are those of the author(s) and do not necessarily represent those of the IMF or IMF policy. Working Papers describe research in progress by the author(s) and are published to elicit comments and to further debate.
\end{abstract}

The paper explores the linkages between the global and domestic monetary gaps, and estimates the effects of monetary gaps on output growth, inflation, and net saving rates using panel data for 20 Asian countries for 1980-2008. We find a significant pass-through of the global monetary gap to domestic monetary gaps, which in turn affect output growth and inflation, in individual emerging market and developing countries in Asia. Notably, we provide evidence that the global monetary condition is partly responsible for the current account surplus in Asia. We also draw implications for monetary policy coordination for global rebalancing.

JEL Classification Numbers:C51; E52; F32

Keywords: monetary policy; global imbalance, monetary transmission; net saving rates; dynamic panel

Author's E-Mail Address:wchoi@,imf.org; ilee@imf.org

\footnotetext{
${ }^{1}$ Woon Gyu Choi is a Senior Economist at the IMF Institute of the International Monetary Fund. Il Houng Lee, currently the IMF Senior Resident Representative in China, was an Advisor at the Asia Pacific Department of the International Monetary Fund when this paper was written. The authors thank Masahiko Takeda and Tao Wu for useful comments and suggestions. They are also grateful to Janice Lee, Larissa Leony, and especially Fernan Ramirez for excellent assistance in the collection of data.
} 


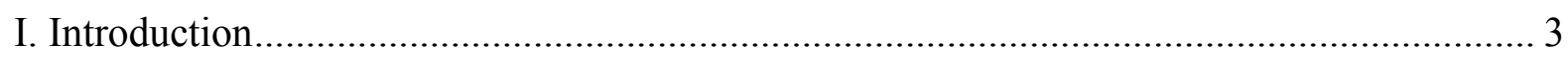

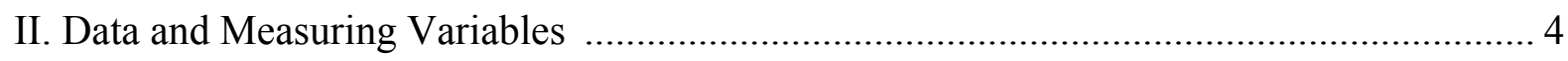

III. Estimating Monetary Policy Inter-linkages .................................................... 10

IV. How Did Monetary Gaps affect Output Growth and Inflation? ................................. 12

V. How Did Monetary Gaps affect Savings, Investment, and Saving Rates? ..................... 16

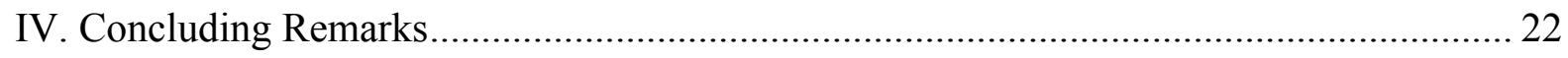

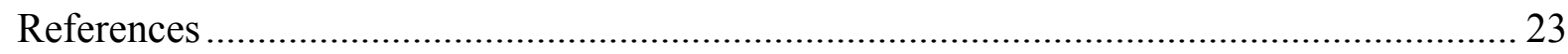

Tables

1. Linkages between Global and Domestic Monetary Gaps ............................................. 11

2. Effects of Monetary Gaps on Output Growth .......................................................... 14

3. Effects of Monetary Gaps on Inflation ....................................................................... 15

4. Effects of Monetary Gaps on Saving, Investment, and Net Saving Rates ....................... 19

Figures

1. Domestic and Global Monetary Gaps ........................................................................ 5

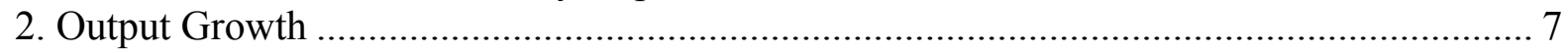

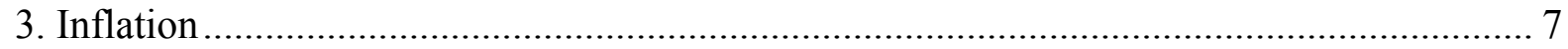

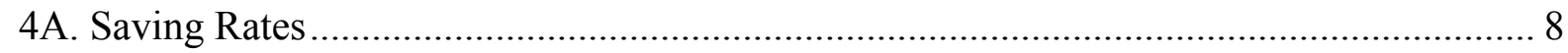

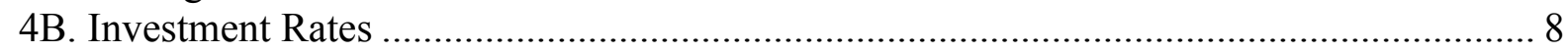

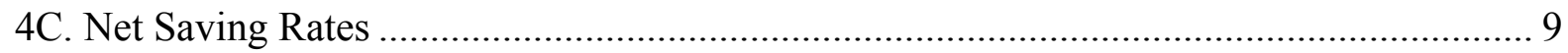

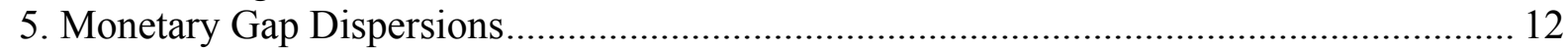

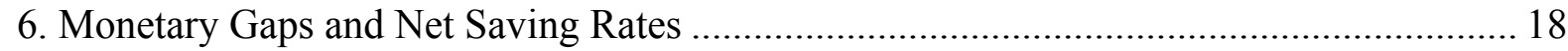

Appendix

A. Country Group List ................................................................................................ 26

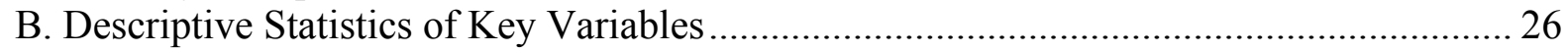




\section{INTRODUCTION}

Financial integration in recent decades has resulted in closer alignment of monetary conditions across countries. While such integration at a time of ample global liquidity may have helped finance investment, emerging market and developing (EMD) countries have faced policy challenges in managing large and volatile capital flows. The appropriateness of the global monetary condition, therefore, needs to be reviewed increasingly in the context of its implication for domestic monetary policy in EMD countries.

This paper explores the linkages between the global and domestic monetary gapsdefined as the gap between the actual real rate and the "neutral" real rate - and their effects on output growth, inflation, and net saving rates for Asian countries. It provides some evidence on the chained links between the global and domestic monetary gaps, and then between the latter and the saving-investment gaps in Asian countries. ${ }^{2}$ This strengthens the argument that global imbalances may ultimately be attributable to the collective sum of internal imbalances caused by inappropriate macroeconomic policies, as alluded by Obstfeld and Rogoff (2009).

The global imbalance has been attributed to multifaceted causes. These include: the savings glut in Asia (Bernanke, 2005); a permanent shift in U.S. government deficits (IMF, 2005); foreign exchange intervention to promote the competitiveness of exporting industry in light of the new mercantilism (Dooley, Folkerts-Landau, and Garber, 2005; and Durdu, Mendoza, and Terrones, 2009); demographic transformation such as aging population (Cooper, 2008); and financial market imperfection and financial integration (Caballero, Farhi, and Gourinchas, 2008; and Mendoza, Quadrini, and Ríos-Rull, 2009). ${ }^{3}$ However, as pointed out by Blanchard and Milesi-Ferretti (2009), it would be wrong to attribute global imbalances to just a few of aforementioned factors. The fact remains that global imbalances have been accompanied by a large global liquidity expansion supported by low policy rates in advanced countries, to which EMD countries had to adapt their domestic monetary policy.

Thus, the impact of the large global liquidity and EMD countries' monetary policy response on their internal imbalances deserves further review. While financial integration has ameliorated the paucity of capital (Lucas, 1990) owing to credit-market imperfections (Reinhart and Rogoff, 2004b), the "push" channel of capital flows (Calvo, Leiderman, Reinhart, 1994, 1996) suggests that low interest rates in advanced countries have pushed capital, at an accelerated pace in the 2000s, into EMD countries. For many emerging market countries, however, the confluence of net capital flows and surpluses in the savinginvestment balance have complicated their macroeconomic management. To contain the

\footnotetext{
${ }^{2}$ Earlier studies (IMF, 2009, 2010; and Obstfeld and Rogoff, 2009) have examined how global real interest rates affect asset prices in capital recipient countries.

${ }^{3}$ Caballero, Farhi, and Gourinchas (2008) make a case that, under financial integration and low interest rates, emerging markets with high growth invest in financial assets supplied by advanced countries with low growth and the relative advantage in producing financial instruments. Mendoza, Quadrini, and Ríos-Rull (2009) suggest that, under financial integration and uncertainty, financially-less-developed countries increase endogenously savings and the demand for U.S. financial assets.
} 
spill-over effect from the external sector on domestic liquidity, central banks have intervened in foreign exchange markets, thereby accumulating international reserves, and/or introduced other policy measures (Ostry and others, 2010). Furthermore, high-growth EMD countries have pushed back capital largely by purchasing U.S. treasuries in the last decade (Astley and others, 2009). Such "uphill" capital flows, especially backed by the accumulated reserves in Asia, may have contributed to the widening saving-investment imbalances (Cova, Pisani, and Rebucci, 2009). Hence, monetary policy adaptations to the global monetary gap may be responsible for the evolution of the saving-investment gap (current account balance) in Asia.

Using annual data for 20 Asian countries for 1980-2008, we use panel regressions to estimate policy inter-linkages and the effects of monetary gaps for the sub-samples of the EMD and advanced (ADV) Asia as well as the pooled sample. Our dynamic panel regression results provide evidence on the inter-linkage between global and domestic monetary gaps in the EMD Asia, implying that the EMD Asia has accommodated global monetary policy. In addition, we find that expansionary monetary policy increased output growth and inflation in Asia persistently over time from dynamic panel regressions that control for relevant macroeconomic factors such as: net capital flows, world growth, international reserves, world inflation, exchange rate depreciation, and the output gap.

We also find from panel regressions with fixed-country effects that the global monetary gap is partly responsible for the widening saving-investment gap in Asia. Expansionary monetary policy reduces investment rates (investment/output) because it increases output proportionately more than investment. The negative effect of expansionary monetary policy on investment rates dominates its effect on saving rates (savings/output), so that net saving rates in Asia rise with the global monetary gap. This outcome has implications for the global monetary policy coordination to achieve global rebalancing.

\section{DAta AND Measuring VARIABLeS}

Annual data of 20 Asian countries for 1980-2008 are drawn from various sources including IMF's International Finance Statistics, World Economic Outlook, and Government Finance Statistics; CEIC; Haver; and the U.S. Census Bureau. The list of country groups and descriptive statistics of key country-specific variables are provided in Appendices A and B.

Monetary gaps are defined as the difference between actual and neutral rates of interest. We use potential real output growth as a proxy for neutral real rates, since real output growth is closely associated with real rates in the equilibrium of a growth model for monetary policy. ${ }^{4}$ Also, the "Keynes-Ramsey rule" in a monetary production economy implies that the marginal rate of substitution (MRS) is equalized to the marginal rate of transformation

\footnotetext{
${ }^{4}$ Clarida, Galí, and Gertler $(2001,2002)$ show that the "neutral" real rate arising in the frictionless equilibrium is the weighted average of the domestic and foreign neutral output growth for an open economy. The weight on foreign neutral growth is zero if the utility function is logarithmic (Clarida, Galí, and Gertler, 2002). In this case, the neutral real rate is linked to the domestic potential growth only (abstracting from constant terms), as in a standard Neo-classical growth model.
} 
Figure 1. Domestic and Global Monetary Gaps

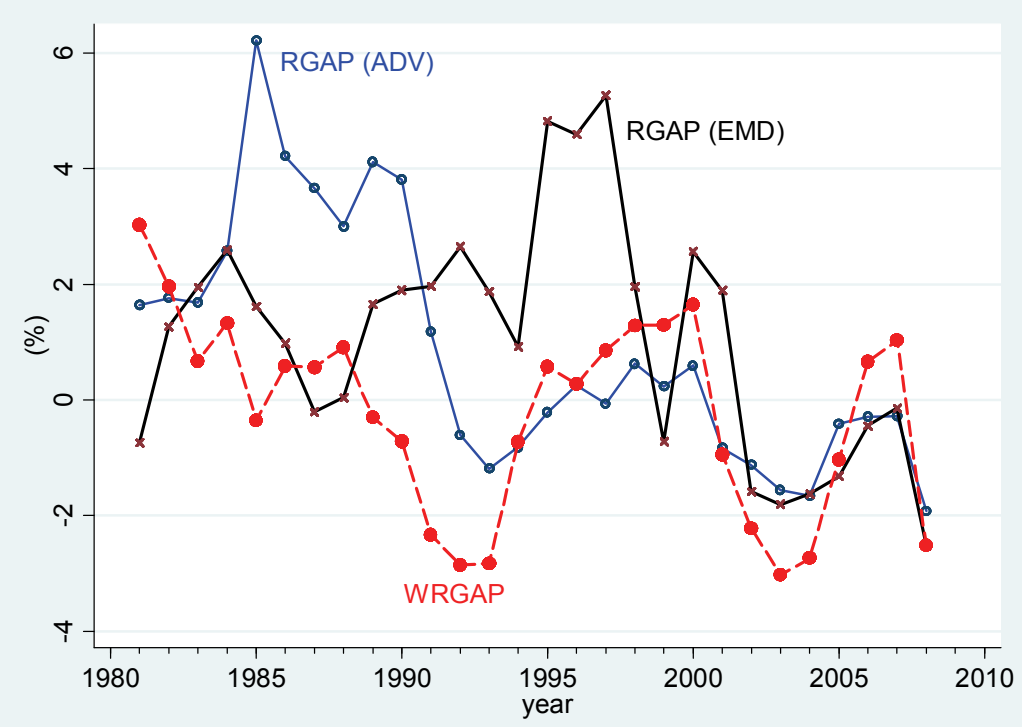

Note: This figure shows the cross-section means of domestic monetary gaps $(R G A P)$ for advanced (ADV) and emerging and developing (EMD) countries in Asia, and the global monetary gap (WRGAP).

(MRT) or marginal product of capital net of depreciation (NMPK) through changes in real interest rates so that $\mathrm{MRS}=\mathrm{MRT}=$ real interest rate holds. A consumption-based asset pricing model suggests the use of output growth as a proxy for MRS, whereas a productionbased model suggests the use of NMPK. Hence, the use of neutral values of either output growth or NMPK as a proxy of the neutral real rate is consistent with theory. ${ }^{5}$

In reality, however, since nominal rates are often partially responsive to inflation (owing to unanticipated shocks or sluggishness in nominal rates), real rates are negatively affected by inflation - an inverted Fisher effect (Carmichael, and Stebbing, 1983; and Choi, 2002). Accounting for links between real rates and real output growth together with the inverted Fisher effect, we measure the neutral real rate as the potential real output growth (gstar) adjusted by the impact of inflation on real rates. For country $i$ at time $t$, the domestic monetary gap is measured by ${ }^{6}$

$$
R G A P_{i, t} \equiv R R_{i, t}-\left(g_{s t a r}+\hat{\gamma} \pi_{i, t}\right)
$$

where $R G A P_{i, t}$ is the domestic monetary gap, $R R_{i, t}$ is the actual real interest rate defined as money market rates minus CPI inflation, gstar is the potential real GDP growth based on the

\footnotetext{
${ }^{5}$ Trehan and $\mathrm{Wu}$ (2007) suggest that neutral rates constructed from a Kalman filter approach are closely associated with the trend growth of real output for the U.S. economy, as implied by Neo-classical growth theory.

${ }^{6}$ Alternative measures of monetary gaps, such as actual real interest rates, yielded qualitatively similar, but less pronounced, results for most regressions.
} 
Hodrick-Prescott stochastic trend, and $\pi_{i, t}$ is CPI inflation. ${ }^{7}$ Coefficient $\hat{\gamma}$, capturing the inverted Fisher effect, is the coefficient estimate on inflation from the constrained least square regression with a unitary coefficient on the potential real GDP growth:

$R R_{i, t}=$ gstar $_{i, t}+\gamma \pi_{i, t}+e_{i, t}$, where $e_{i, t}$ is an error term. Likewise, the global monetary gap (WRGAP) is the spread between the (three-month) real LIBOR (that equals nominal LIBOR - advanced countries' average inflation) and the average potential growth of advanced countries (based on the Hodrick-Prescott stochastic trend). The average inflation of advanced countries is assumed to be largely expected so that the inverted Fisher effect is nil. ${ }^{8}$

The measure of domestic monetary gaps $(R G A P)$ is much more volatile for the EMD (standard deviation is 6.9 compared with 4.2 for the ADV Asia). RGAP ranges as wide as 28 and 34 reflecting country heterogeneity, compared with WRGAP in the range of -3 and 3 . Figure 1 depicts the cross-section mean of RGAP for the ADV Asia and EMD Asia, and $W R G A P$ for 1980-2008. The figure shows closer co-movements between the global monetary gap and domestic monetary gaps in Asia in the 2000s than earlier. The peak in the cross-section mean of $R G A P$ is associated with persistent disinflation in the first half of the 1980s (the mid-1990s) for the ADV (EMD) Asia.

Movements of macroeconomic variables (see Appendix B) can be summarized as follows.

- Output growth and CPI inflation are on average higher in the EMD Asia by about 2 and 11 percent, respectively, than for the ADV Asia. Output growth and inflation are widely dispersed among the EMD Asia, especially before the 2000s, as shown in Figures 2-3. The output gap is on average close to zero by construction, but more volatile for the EMD Asia than for the ADV Asia.

- Saving rates are on average somewhat higher for the ADV Asia (27 percent) than for the EMD Asia (24 percent). Saving rates for both groups of countries show rising trends (Figure 4A), which may reflect aging population in Asia.

- Investment rates are on average similar at around 25 percent for both country groups, and show a rising trend for the EMD Asia in recent years after a substantial drop following the 1997 Asian crisis (Figure 4B).

- Net saving rates, as measured by the percentage ratio of current account balance to GDP, are on average higher for the ADV Asia (1.5 percent compared with -1.6 percent for the EMD Asia). Net saving rates shifted up after the Asian crisis, more for the EMD countries (Figure 4C).

\footnotetext{
${ }^{7}$ The neutral rate measure is abstracted from population growth, steady over time, and a fixed discount factor, which are taken into account by fixed-country effects or washed out in dynamic panel specifications. We note that redefining gstar as the potential real output growth per capita yielded almost the same regressions results.

${ }^{8}$ The inverted Fisher effect on real interest rates for Asian countries is estimated at -0.56 , but that real LIBOR rates is estimated at a value close to zero.
} 
Figure 2. Output Growth

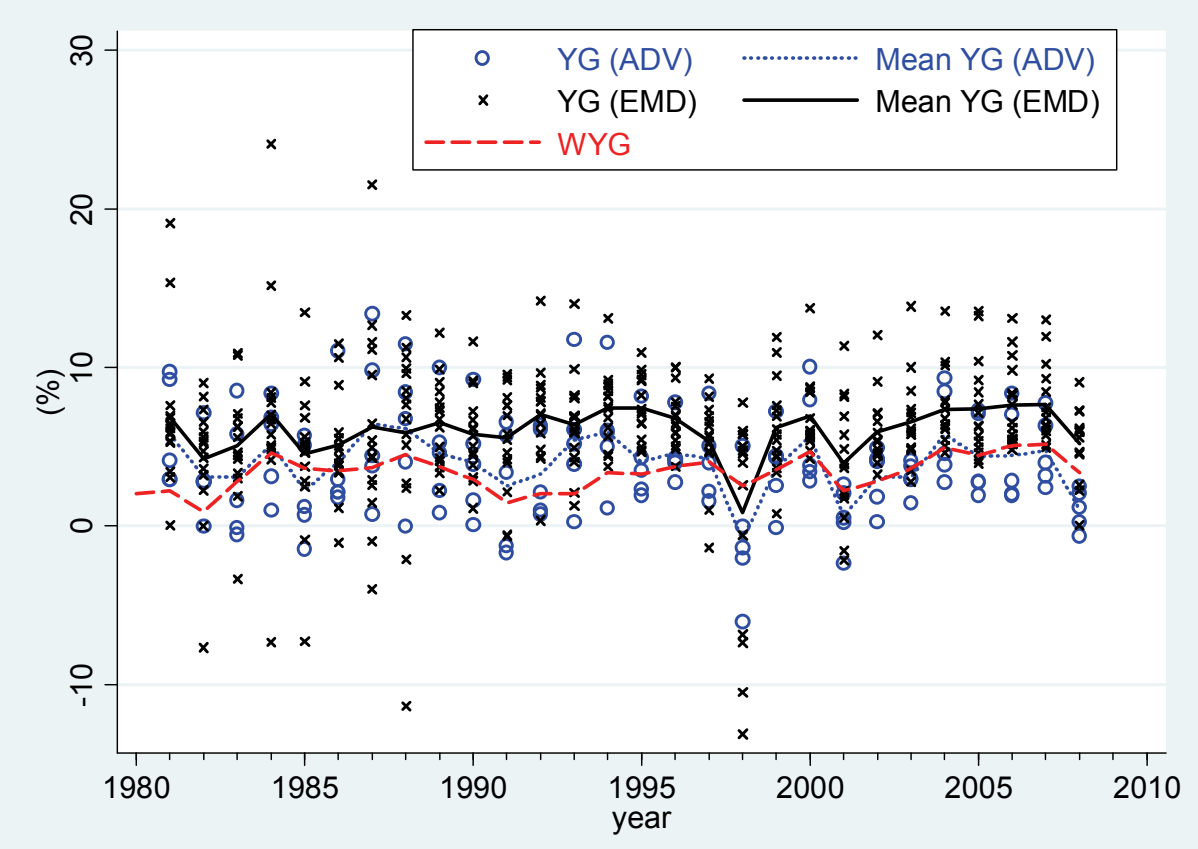

Note: This figure shows output growth $(Y G)$ for advanced (ADV) and emerging and developing (EMD) countries in Asia, along with their cross-section means, and world output growth $(W Y G)$.

Figure 3. Inflation (CPI)

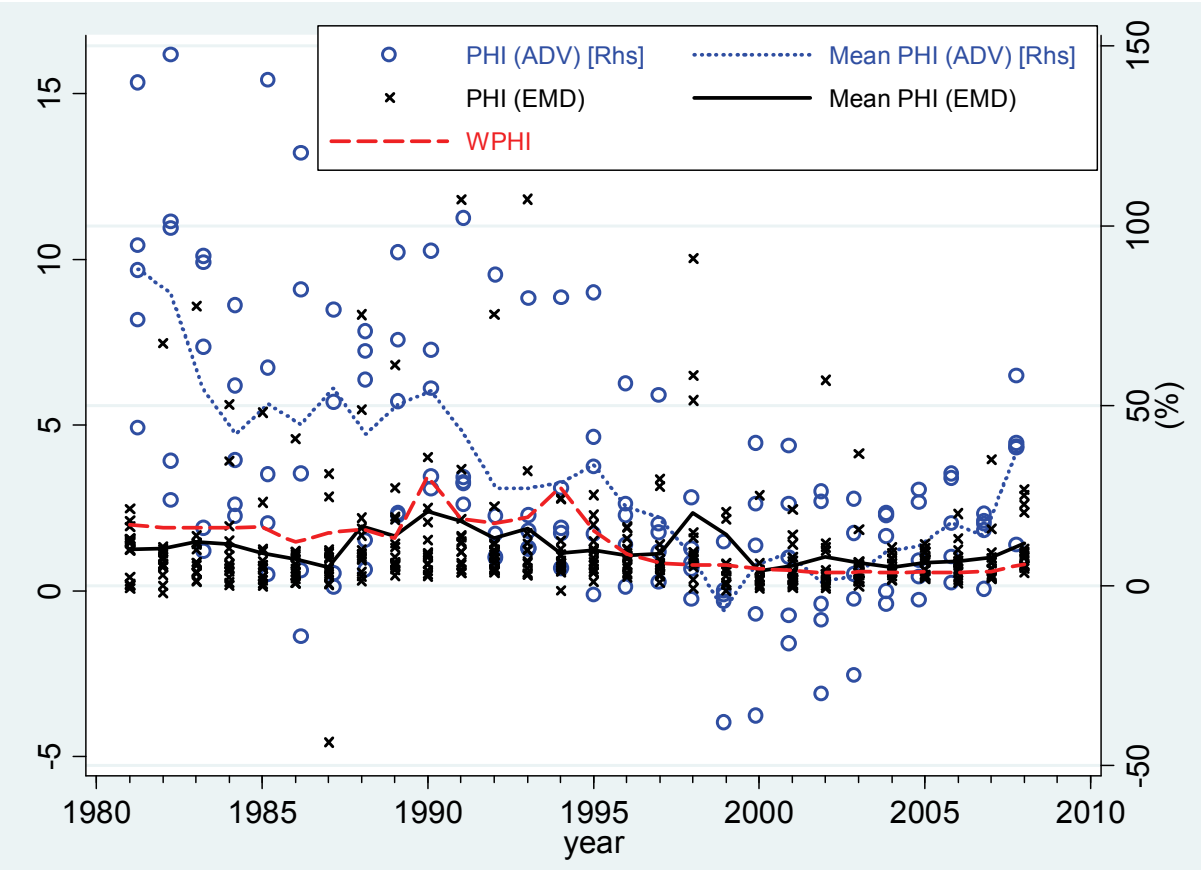

Notes: This figure shows CPI inflation (PHI) for advanced (ADV) and emerging and developing (EMD) countries in Asia, along with their cross-section means, and world CPI inflation (WPHI). Vietnam, which has the maximum value of over 400 percent inflation, is excluded as an outlier in this figure. Inflation for ADV countries are scaled on the right hand side [Rhs]. 
Figure 4A. Saving Rates

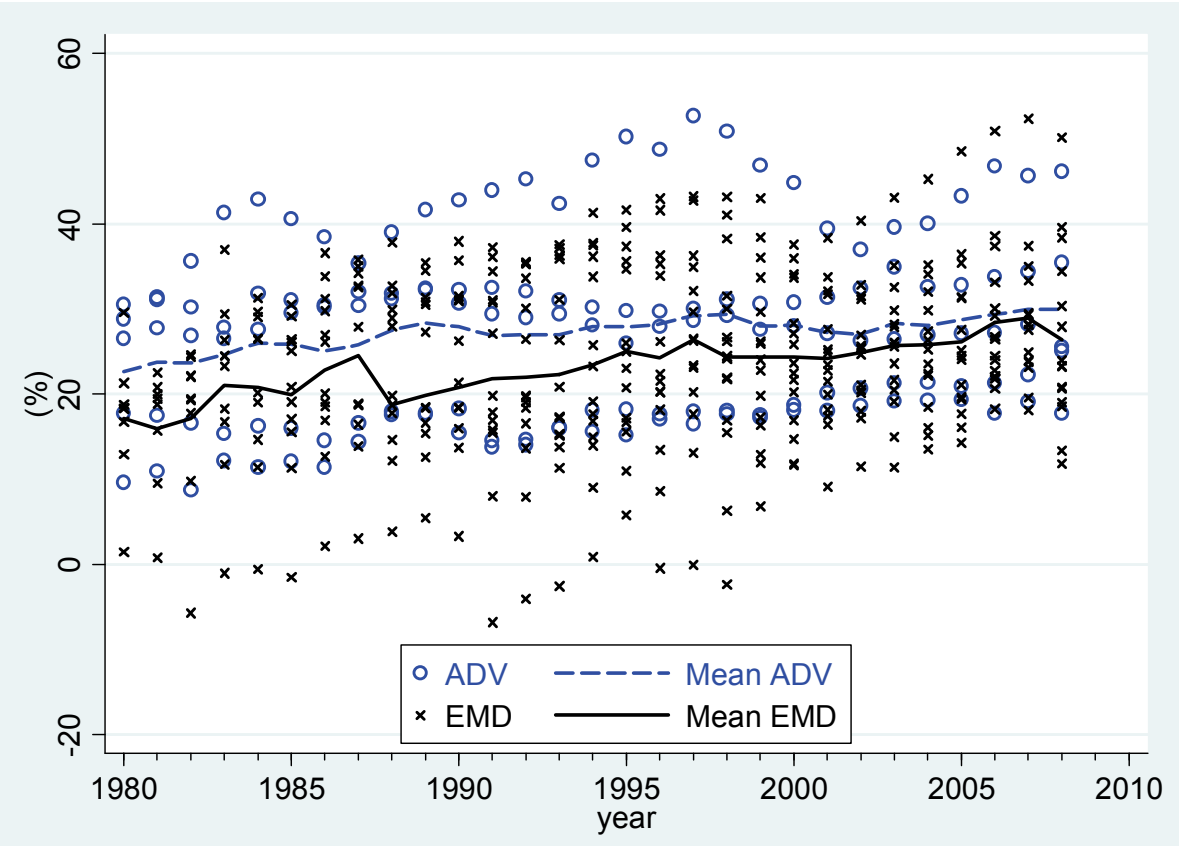

Notes: This figure shows saving rates $(S / Y)$ for advanced (ADV) and emerging and developing (EMD) countries in Asia, along with their cross-section means. Singapore has the highest saving rates, and Cambodia (not included here) has the lowest saving rates.

Figure 4B. Investment Rates

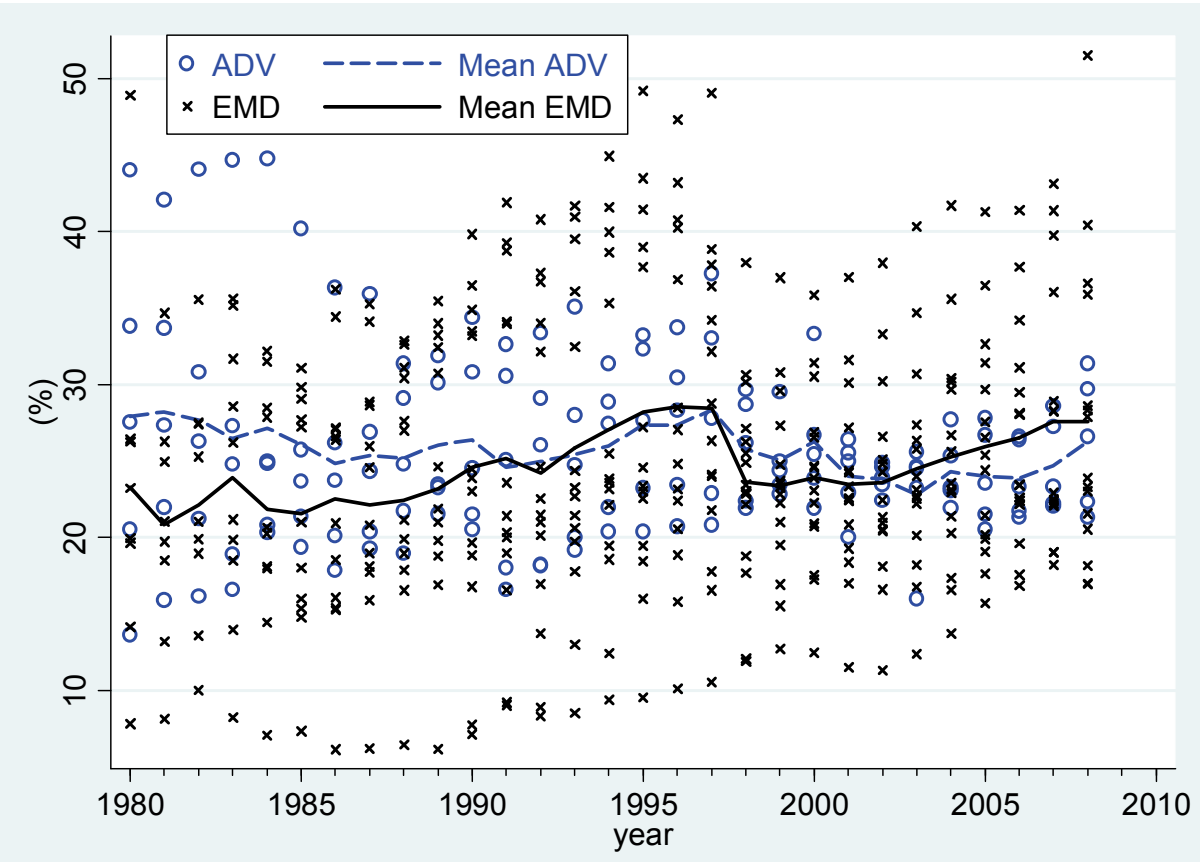

Notes: This figure shows investment rates (I/Y) for advanced (ADV) and emerging and developing (EMD) countries in Asia, along with their cross-section means. Vietnam has the highest investment rates in 2008-2009, outpacing China. 
Figure 4C: Net Saving Rates

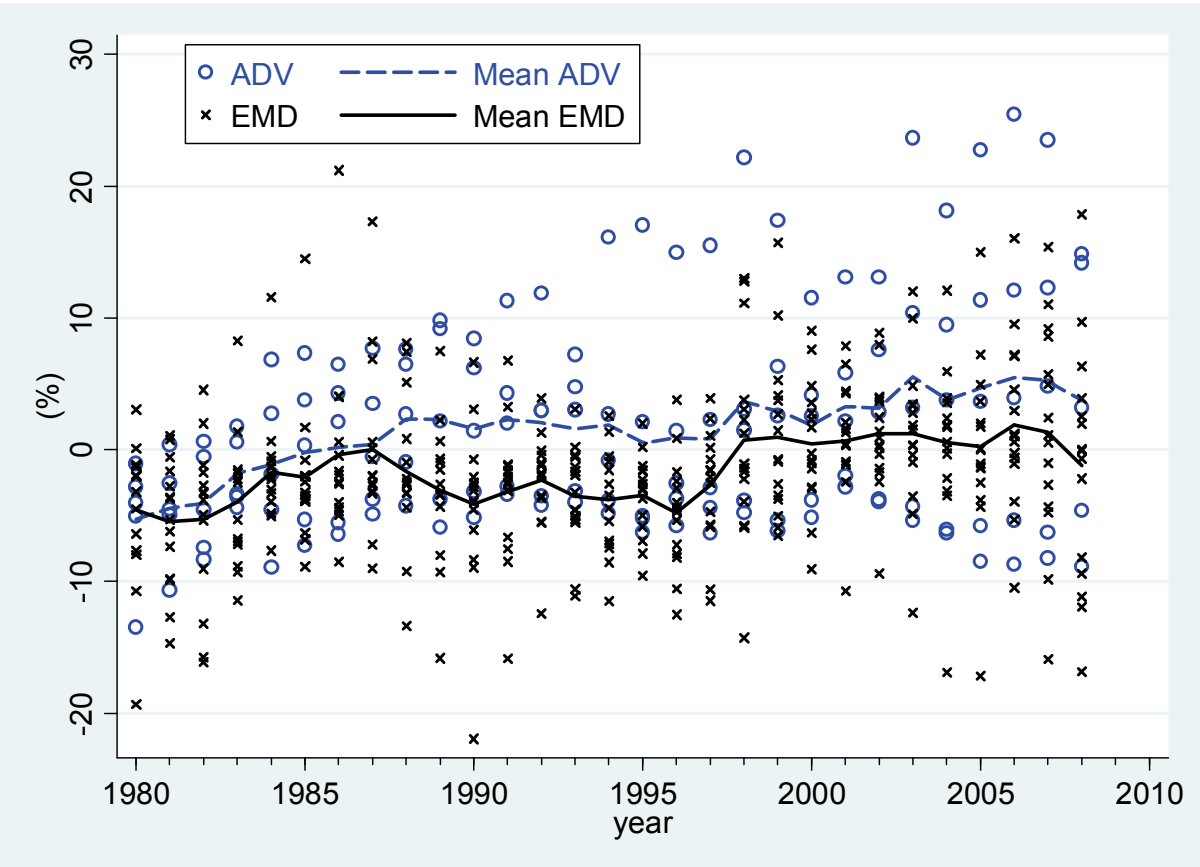

Note: This figure shows net saving rates $(N S / Y)$ for advanced (ADV) and emerging and developing (EMD) countries in Asia, along with their cross-section means.

- Net capital flows, measured as the capital and financial account of the balance of payments to GDP, are higher for the EMD Asia than for the ADV Asia by about 2.8 percent of GDP. International reserves are defined as gross reserves net of gold (Choi, Sharma, and Strömqvist, 2009). Reserves relative to GDP are higher for the EMD Asia (29 percent) than for the ADV Asia (13 percent).

- Exchange rate growth (a positive growth means a depreciation of a country's currency) is much higher for the EMD Asia (about 12 percent compared with less than 1 percent for the ADV Asia). Exchange rate growth and inflation are much more volatile for the EMD Asia than for ADV Asia.

The demographic structure of a country is captured by two dependency ratios using the U.S. Census Bureau data: the aged dependency (65-and-above to total population) ratio and the youth dependency (under-15 to total population) ratio. The youth dependency ratio is about twice higher for the EMD countries (59 percent compared with 31 percent for the ADV Asia), whereas the aged dependency ratio is only about a half for the EMD Asia (8 percent compared with 16 percent for the ADV Asia). For 1980-2008, the (cross-section-average) youth dependency ratio monotonically declined from 73 percent to 43 percent for the EMD Asia (40 percent to 25 percent for the ADV Asia), whereas the aged dependency ratio monotonically rose from 7 percent to 9 percent for the EMD Asia (12 percent to 20 percent for the ADV Asia). 
We measure a country-specific financial integration by the sum of the stock of portfolio equity assets and liabilities and the stock of foreign direct investment (FDI) assets and liabilities as percent of GDP in logarithm — using the data from Lane and Milesi-Ferretti (2007) and from Haver's International Investment Position. The degree of integration is much higher for the ADV Asia (on average 2.9 compared with 0.2 for the EMD Asia).

\section{Estimating Monetary Policy InTER-Linkages}

Generally, the transmission of the global monetary gap to domestic monetary gaps would be stronger in countries with greater openness to global financial markets. Countries pursuing policy independence through exchange rate flexibility can better insulate the domestic economy from pervasive global liquidity shocks that could fuel asset prices and inflation. Conversely, countries that accommodate the global monetary gap through foreign exchange interventions can benefit from the push channel of capital flows when global liquidity expands. ${ }^{9}$ Since foreign exchange intervention with no sterilization is likely lead to inflationary pressures, countries often take a middle-ground strategy to dampen the impacts of capital inflows using sterilization with moderate exchange rate flexibility.

We consider an empirical model for policy inter-linkages to assess the transmission of the global monetary gap to domestic monetary gaps $(R G A P)$. For country $i$ at time $t$, the domestic monetary gap is determined by

$$
R G A P_{i, t}=\alpha_{i}+\alpha_{W R} W R G A P_{t}+\alpha_{Z} Z_{i}+\varepsilon_{i, t},
$$

where $W G A P_{t}$ is the global monetary gap that is constant across countries but varies over time, $\alpha_{i}$ is the coefficient that reflects fixed-country effects, $Z_{i}$ captures country characteristics that are largely fixed over time (for example, the underlying monetary or exchange rate regime), and $\varepsilon_{j, t}$ an error term. Under a perfect (imperfect) pass-through of monetary gaps, $\alpha_{W R}=1\left(0<\alpha_{W R}<1\right)$.

To account for dynamic adjustments in policy inter-linkages, we set up a dynamic panel regression model by first differencing equation (2) and including lagged dependent variables. Variables for fixed-country effects and other "fixed" country characteristics over the sample period (such as $Z_{i}$ ) are dropped from the dynamic panel model. The dynamic panel counterpart of equation (2) is represented by:

$$
\begin{aligned}
\Delta R G A P_{i, t}= & \alpha_{R G, 1} \Delta R G A P_{i, t-1}+\alpha_{R G, 2} \Delta R G A P_{i, t-2} \\
& +\alpha_{W R, 0} \Delta W R G A P_{i, t}+\alpha_{W R, 1} \Delta W R G A P_{i, t-1}+u_{i, t},
\end{aligned}
$$

\footnotetext{
${ }^{9}$ Existing studies (Calvo, Leiderman, Reinhart, 1994, 1996) suggest "push" and "pull” channels of capital flows. External factors including economic cycles, low interest rates, and financial structure developments in advanced countries push capital into EMD countries. Internal factors including reforms, such as financial market liberalization, tighter fiscal policy, and better prospects in growth pull into EMD countries.
} 
Table 1. Linkages between the Global and Domestic Monetary Gaps:

Dynamic Panel Regressions

\begin{tabular}{|c|c|c|c|c|c|c|}
\hline \multirow{2}{*}{$\begin{array}{l}\text { Independent } \\
\text { Variables }\end{array}$} & \multicolumn{2}{|c|}{ Pooled } & \multicolumn{2}{|c|}{ ADV Asia } & \multicolumn{2}{|c|}{ EMD Asia } \\
\hline & (a) & (b) & (a) & (b) & (a) & (b) \\
\hline$\triangle R G A P_{-1}$ & $\begin{array}{l}0.577 * * * \\
(7.41)\end{array}$ & $\begin{array}{l}0.567^{* * * *} \\
(7.02)\end{array}$ & $\begin{array}{l}0.707 * * * \\
(12.57)\end{array}$ & $\begin{array}{l}0.618^{* * *} \\
(21.98)\end{array}$ & $\begin{array}{l}0.555^{* * *} \\
(6.84)\end{array}$ & $\begin{array}{l}0.553^{* * *} \\
(6.53)\end{array}$ \\
\hline$\triangle R G A P_{-2}$ & $\begin{array}{l}-0.224 \\
(-1.60)\end{array}$ & $\begin{array}{l}-0.221 \\
(-1.59)\end{array}$ & -- & -- & $\begin{array}{l}-0.262^{*} \\
(-1.82)\end{array}$ & $\begin{array}{l}-0.253^{*} \\
(-1.75)\end{array}$ \\
\hline$\triangle W R G A P$ & $\begin{array}{l}0.503 * * * \\
(4.41)\end{array}$ & -- & $\begin{array}{l}0.342 * * * \\
(3.04)\end{array}$ & -- & $\begin{array}{l}0.599 * * * \\
(4.22)\end{array}$ & -- \\
\hline$\triangle W R G A P_{-1}$ & $\begin{array}{l}-0.130 \\
(-1.42)\end{array}$ & -- & -- & -- & $\begin{array}{l}-0.222 \\
(-1.72)\end{array}$ & -- \\
\hline$\triangle U S F F R$ & -- & $\begin{array}{l}0.587^{* * * *} \\
(5.36)\end{array}$ & -- & $\begin{array}{l}0.333^{* *} \\
(5.91)\end{array}$ & -- & $\begin{array}{l}0.636^{* * *} \\
(4.48)\end{array}$ \\
\hline$\triangle U S F F R_{-1}$ & -- & $\begin{array}{l}-0.195^{* *} \\
(-2.20)\end{array}$ & -- & -- & -- & $\begin{array}{l}-0.280^{* *} \\
(-2.20)\end{array}$ \\
\hline Wald test: $\chi^{2}(n)$ & $114.8[0.000]$ & $172.0[0.000]$ & $524.8[0.000]$ & $617.9[0.000]$ & 100.8 [0.000] & $116.2[0.000]$ \\
\hline No. of observations & 425 & 425 & 117 & 121 & 309 & 309 \\
\hline $\begin{array}{l}\text { Arellano-Bond tests: } \\
\text { [order1, order 2] }\end{array}$ & {$[0.03,0.49]$} & {$[0.03,0.46]$} & {$[0.23,0.50]$} & {$[0.23,0.46]$} & {$[0.04,0.56]$} & {$[0.04,0.49]$} \\
\hline
\end{tabular}

Notes: This table shows the results of regression model (3) for the pooled sample, five advanced (ADV), and 15 emerging and developing (EMD) countries in Asia for the 1980-2008 period using the Arellano-Bond (1991) GMM method. The dependent variable is the domestic monetary gap $(R G A P)$. The $z$-ratios in parentheses are based on standard errors robust to heteroscedasticity. Significance at the one, five, and ten percent level is given by $* * *, * *$, and $*$, respectively. Wald test statics follows $\chi^{2}(n)$ distribution, where $n$ is the number of regressors except the constant term (with $p$-values in square brackets). The statistics for the Arellano-Bond tests are based on the null hypothesis of no autocorrelation of order 1 and 2 (with $p$-values in square brackets).

where $u_{i, t}$ is an error term. We estimate this dynamic panel model using Arellano and Bond's (1991) Generalized Method of Moments (GMM) estimator. We report $z$-ratios based on standard errors robust to heteroscedasticity.

As shown in Table 1, the estimated results of dynamic panel data models suggest that the global monetary gap has significantly affected domestic monetary gaps for Asian countries. Monetary gaps of the EMD Asia are about twice as sensitive to the global monetary gap in the short run as to those of the ADV Asia, but the reverse is true in the long run. Specifically, results in column (a) suggest that a one-percent-point increase in the global monetary gap increases in domestic monetary gaps in the short run (long run) by about 0.34 (1.07) percentage point for the ADV Asia, and $0.60(0.53)$ percentage point for the EMD Asia. The inclusion of the U.S. federal funds rate, USFFR, in place of WRGAP yields similar results of the global monetary stance on RGAP (column (b)). Also, the use of the three-month LIBOR in place of USFFR provides very similar results (not reported). 
Figure 5: Monetary Gap Dispersions

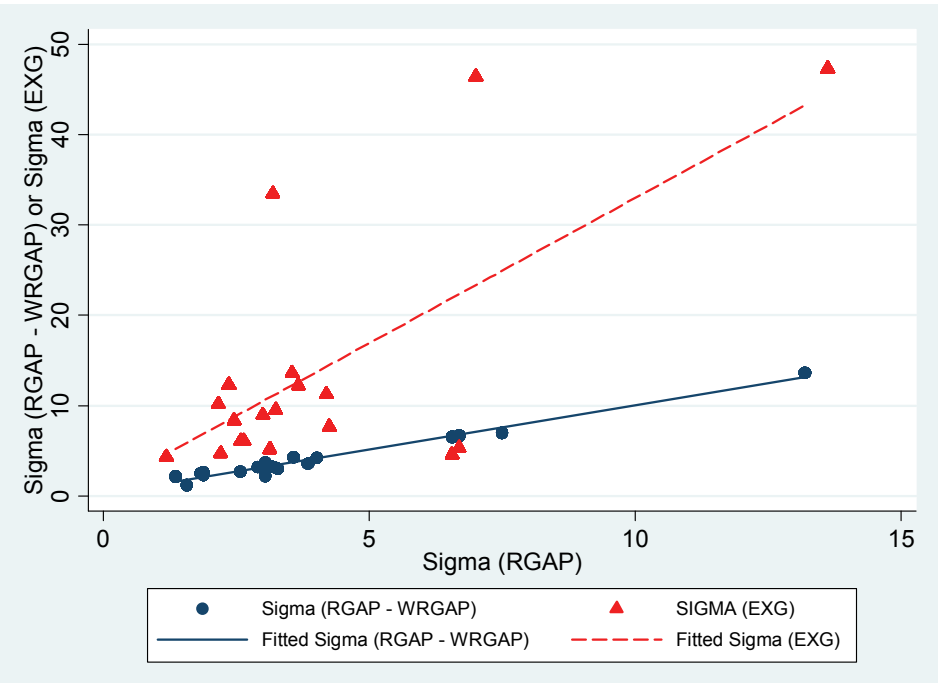

Note: This figure shows that the standard deviations of monetary gaps $(R G A P)$ is very closely linked to those of the spread between $R G A P$ and the global monetary gap (WRGAP) for Asian countries (with $R^{2}=0.97$ ); and somewhat positively related to those of exchange rate growth $(E X G)$ for Asian countries except Vietnam that has extreme exchange rate volatility (with $R^{2}=0.45$ ).

The estimated results support the existence of dynamic policy inter-linkages. The coefficient on the one-period lagged dependent variable has a statistically significant coefficient in the range of $0.5-0.7$, indicating substantial persistence in monetary gaps. The contemporaneous positive impacts of WRGAP or USFFR are partly offset in the following period, since the coefficient on the two-period lagged variable is negative for the pooled and EMD Asia. The Wald test statistics indicate the joint significance of the regressors. As the Arellano-Bond estimator assumes first-order autocorrelation and no second-order autocorrelation of the residuals, the serial correlation tests do not indicate misspecification for the pooled and EMD Asia. For the ADV Asia, no evidence on both the first- and secondorder serial correlations may reflect a moving average component in errors, which is largely offset in the first-difference form.

The evidence on the policy inter-linkages indicates that interventions, rather than exchange rate adjustments, have been the first line of defense in dealing with capital flows for the EMD Asia. We also note that countries with larger dispersions in monetary gaps have looser links with the global monetary gap and tend to have larger exchange rate variability (see Figure 5).

\section{How Did Monetary Gaps AfFect OUtPut Growth And Inflation?}

We estimate the dynamic impact of domestic monetary gaps on output growth and inflation for Asian country groups using dynamic panel regressions. Regressions are specified as a reduced form, allowing for the endogeneity of regressors. 
The dynamic panel regression for output growth is represented by:

$$
\begin{aligned}
\Delta Y G_{i, t}= & \beta_{Y G, 1}^{Y} \Delta Y G_{i, t-1}+\beta_{Y G, 2}^{Y} \Delta Y G_{i, t-2}+\beta_{R G, 0}^{Y} \Delta R G A P_{i, t}+\beta_{R G, 1}^{Y} \Delta R G A P_{i, t-1} \\
& +\beta_{C F}^{Y} \Delta\left(\frac{N C F}{Y}\right)_{i, t}+\beta_{W Y}^{Y} \Delta W Y G_{t}+\beta_{P H}^{Y} \Delta P H I_{i, t}+\beta_{I R}^{Y} \Delta\left(\frac{I R}{Y}\right)_{i, t}+u_{i, t}^{Y},
\end{aligned}
$$

where $(N C F / Y)_{i, t}$ is the net capital flows to output ratio, $W Y G_{t}$ is world output growth which is the same across countries but varies over time, $P H I_{i, t}$ is CPI inflation, $(I R / Y)_{i, t}$ is the international reserves to output ratio, and $u_{i, t}$ an error term.

Net capital flows can support economic growth through the financing of investment (for example, Bosworth and Collins, 1999). World output growth also promotes Asian countries' output growth by increasing the demand for their exports. Output growth is negatively associated with inflation through: (i) inflation tax effects (for example, Cooley and Hansen, 1989); and (ii) concomitant exchange rate depreciations and adverse balance sheet effects (for example, Choi and Cook, 2004; and Elekdag and Tchakarov, 2007). International reserve accumulation could crowd out investment (see discussions on the investment rate regression) and thereby reduce output growth while international reserves provide a buffer against shocks from capital flows and current accounts, helping smooth out output fluctuations. Accounting for possible feedback effects from (current and future) output growth on domestic monetary gaps, inflation, and reserve holdings, we treat $R G A P, P H I$, and $I R / Y$ as endogenous regressors.

Tighter monetary policy has a significant negative impact on output growth, especially for the EMD Asia, as shown in Table 2. For the EMD Asia, column (b) regressions suggest that a one-percent-point increase in $R G A P$ results in a decrease in output growth on average by 0.20 and 0.30 percent points, respectively, in the short run and long run. Output growth shows mild persistence as indicated by the coefficient on the one-period-lagged dependent variable estimated to be around 0.2 for all groups. Both net capital flows and world economic growth have positive effects on output growth. Output growth is negatively associated with inflation for the pooled sample and EMD Asia. This finding reflects that high inflation tends to be detrimental to growth in the EMD Asia where inflation on average is relatively high (14.3 percent) but not for the ADV Asia with low inflation (3.5 percent), consistent with the threshold effect literature on growth in cross-country studies (for example, Khan and Senhadji, 2001). Further, output growth is negatively associated with the international reserves to GDP ratio, likely reflecting that excessive reserve accumulations accompanied by sterilization may have staved off investment (to below the discussion on investment rate regression results). All coefficients are consistent with expected signs, and jointly significant as indicated by the Wald test statistics. The serial correlation tests do not indicate misspecification for all groups, while, for the advanced Asia group, the second-order correlation is (weakly) rejected at the 10 percent significance level. 
Table 2. Effects of Monetary Gaps on Output Growth Dynamic Panel Regressions

\begin{tabular}{|c|c|c|c|c|c|c|}
\hline \multirow{2}{*}{$\begin{array}{l}\text { Independent } \\
\text { Variables }\end{array}$} & \multicolumn{2}{|c|}{ Pooled } & \multicolumn{2}{|c|}{ ADV Asia } & \multicolumn{2}{|c|}{ EMD Asia } \\
\hline & (a) & (b) & (a) & (b) & (a) & (b) \\
\hline$\Delta Y G_{-1}$ & $\begin{array}{l}0.241 \text { *** } \\
(3.71)\end{array}$ & $\begin{array}{l}0.231^{* * * *} \\
(3.98)\end{array}$ & $\begin{array}{l}0.197 * * \\
(2.43)\end{array}$ & $\begin{array}{l}0.179 * * \\
(2.38)\end{array}$ & $\begin{array}{l}0.254^{* * * *} \\
(3.29)\end{array}$ & $\begin{array}{l}0.234^{* * *} \\
(3.50)\end{array}$ \\
\hline$\Delta Y G_{-2}$ & $\begin{array}{l}-0.106^{* * *} \\
(-3.16)\end{array}$ & $\begin{array}{l}-0.078 * * * \\
(-2.72)\end{array}$ & $\begin{array}{l}-0.128^{* *} \\
(-2.35)\end{array}$ & $\begin{array}{l}-0.141 * * * \\
(-2.82)\end{array}$ & $\begin{array}{l}-0.104^{* *} \\
(-2.43)\end{array}$ & $\begin{array}{l}-0.071 * * \\
(-1.99)\end{array}$ \\
\hline$\triangle R G A P$ & $\begin{array}{l}-0.091 * \\
(-1.75)\end{array}$ & $\begin{array}{l}-0.178 * * * \\
(-3.86)\end{array}$ & $\begin{array}{l}-0.158^{*} \\
(-1.61)\end{array}$ & $\begin{array}{l}-0.186^{*} \\
(-1.90)\end{array}$ & $\begin{array}{l}-0.096^{*} \\
(-1.61)\end{array}$ & $\begin{array}{l}-0.197 * * * \\
(-3.70)\end{array}$ \\
\hline$\triangle R G A P_{-1}$ & $\begin{array}{l}-0.082^{* *} \\
(-2.08)\end{array}$ & $\begin{array}{l}-0.051^{* *} \\
(-1.96)\end{array}$ & -- & -- & $\begin{array}{l}-0.077^{* *} \\
(-1.94)\end{array}$ & $\begin{array}{l}-0.052 * * \\
(-2.04)\end{array}$ \\
\hline$\Delta(N C F / Y)$ & $\begin{array}{l}0.122 * * * \\
(3.15)\end{array}$ & $\begin{array}{l}0.102 * * * \\
(2.66)\end{array}$ & $\begin{array}{l}0.092 * * * \\
(2.68)\end{array}$ & $\begin{array}{r}0.032 \\
(1.09)\end{array}$ & $\begin{array}{l}0.138^{* *} \\
(2.35)\end{array}$ & $\begin{array}{l}0.134^{* *} \\
(2.48)\end{array}$ \\
\hline$\Delta W Y G$ & $\begin{array}{l}0.617 * * * \\
(5.77)\end{array}$ & $\begin{array}{l}0.674 * * * \\
(5.99)\end{array}$ & $\begin{array}{l}0.909^{* * *} \\
(4.52)\end{array}$ & $\begin{array}{l}1.109^{* * *} \\
(4.71)\end{array}$ & $\begin{array}{l}0.525^{* * *} \\
(4.44)\end{array}$ & $\begin{array}{l}0.531^{* * *} \\
(4.63)\end{array}$ \\
\hline$\triangle P H I$ & -- & $\begin{array}{l}-0.095 * * * \\
(-3.18)\end{array}$ & -- & -- & -- & $\begin{array}{l}-0.103 * * * \\
(-3.19)\end{array}$ \\
\hline$\Delta(I R / Y)$ & -- & $\begin{array}{l}-0.058^{* * *} \\
(-3.33)\end{array}$ & -- & $\begin{array}{l}-0.070 * * * \\
(-6.10)\end{array}$ & -- & $\begin{array}{l}-0.061 * * * \\
(-2.64)\end{array}$ \\
\hline Wald test: $\chi^{2}(n)$ & $143.3[0.000]$ & $213.7[0.000]$ & $28.5[0.000]$ & $120.4[0.000]$ & $111.8[0.000]$ & $279.6[0.000]$ \\
\hline No. of observations & 433 & 433 & 118 & 118 & 316 & 316 \\
\hline $\begin{array}{l}\text { Arellano-Bond tests: } \\
\text { [order1, order 2] }\end{array}$ & {$[0.00,0.83]$} & {$[0.01,0.90]$} & {$[0.05,0.11]$} & {$[0.05,0.10]$} & {$[0.01,0.72]$} & {$[0.03,0.64]$} \\
\hline
\end{tabular}

Notes: This table shows the results of regression model (4) for the pooled sample, five advanced (ADV), and 15 emerging and developing (EMD) countries in Asia for the 1980-2008 period using the Arellano-Bond (1991) GMM method. The dependent variable is real GDP growth $(Y G)$. The net capital flows-GDP ratio $(N C F / Y)$, inflation $(P H I)$, and reserves-GDP ratio $(I R / Y)$ are treated as endogenous. The $z$-ratios in parentheses are based on standard errors robust to heteroscedasticity. Significance at the one, five, and ten percent level is given by ***,**, and ${ }^{*}$, respectively. Wald test statics follow $\chi^{2}(n)$ distribution, where $n$ is the number of regressors except the constant term (with $p$-values in square brackets). The statistics for the Arellano-Bond tests are based on the null hypothesis of no autocorrelation of order 1 and 2 (with $p$-values in square brackets).

We introduce a cross-country-augmented Phillips curve for open economies with monetary gaps. The dynamic panel regression for inflation is represented by:

$$
\begin{aligned}
\Delta P H I_{i, t} & =\beta_{P H, 1}^{P} \Delta P H I_{i, t-1}+\beta_{P H, 2}^{P} \Delta P H I_{i, t-2}+\beta_{R G, 0}^{P} \Delta R G A P_{i, t}+\beta_{R G, 1}^{P} \Delta R G A P_{i, t-1} \\
& +\beta_{W H}^{P} \Delta W H P I_{t}+\beta_{E X}^{P} \Delta E X G_{i, t}+\beta_{Y G}^{P} \Delta(Y G A P)_{i, t}+u_{i, t}^{P},
\end{aligned}
$$

where $W_{P H I}$ is world CPI inflation which is the same across countries but varies over time, $E X G_{i, t}$ is (nominal) exchange rate growth, $Y G A P_{i, t}$ is the output gap (defined as the percentage deviation of actual output from potential output), and $u_{i, t}^{P}$ is an error term. 
Table 3. Effects of Monetary Gaps on Inflation

Dynamic Panel Regressions

\begin{tabular}{|c|c|c|c|c|c|c|}
\hline \multirow{2}{*}{$\begin{array}{l}\text { Independent } \\
\text { Variables }\end{array}$} & \multicolumn{2}{|c|}{ Pooled } & \multicolumn{2}{|c|}{ ADV Asia } & \multicolumn{2}{|c|}{ EMD Asia } \\
\hline & (a) & (b) & (a) & (b) & (a) & (b) \\
\hline$\Delta P H I_{-1}$ & $\begin{array}{l}0.490^{* * *} \\
(11.31)\end{array}$ & $\begin{array}{l}0.388^{* * *} \\
(6.95)\end{array}$ & $\begin{array}{l}0.764 * * * \\
(7.08)\end{array}$ & $\begin{array}{l}0.714 * * * \\
(5.37)\end{array}$ & $\begin{array}{l}0.453^{* * *} \\
(18.34)\end{array}$ & $\begin{array}{l}0.354^{* * * *} \\
(6.37)\end{array}$ \\
\hline$\triangle P H I_{-2}$ & $\begin{array}{l}-0.164 * * * \\
(-2.78)\end{array}$ & $\begin{array}{l}-0.115^{* *} \\
(-2.19)\end{array}$ & $\begin{array}{l}-0.112 * * * \\
(-2.77)\end{array}$ & $\begin{array}{l}-0.127 * * \\
(-2.43)\end{array}$ & $\begin{array}{l}-0.159 * * * \\
(-2.43)\end{array}$ & $\begin{array}{l}-0.105^{* *} \\
(-1.92)\end{array}$ \\
\hline$\triangle R G A P$ & $\begin{array}{l}-0.834 * * * \\
(-3.53)\end{array}$ & $\begin{array}{l}-0.710^{* * *} \\
(-3.71)\end{array}$ & $\begin{array}{l}0.174 \\
(0.54)\end{array}$ & $\begin{array}{l}0.053 \\
(0.28)\end{array}$ & $\begin{array}{l}-0.906^{* * *} \\
(-4.16)\end{array}$ & $\begin{array}{l}-0.812 * * * \\
(-4.55)\end{array}$ \\
\hline$\triangle R G A P_{-1}$ & $\begin{array}{l}0.407 * * \\
(2.50)\end{array}$ & -- & $\begin{array}{l}-0.158 \\
(-0.95)\end{array}$ & -- & $\begin{array}{l}0.376^{* *} \\
(2.69)\end{array}$ & -- \\
\hline$\triangle W P H I$ & $\begin{array}{l}0.138 * * * \\
(5.78)\end{array}$ & $\begin{array}{l}0.179^{* * *} \\
(4.32)\end{array}$ & $\begin{array}{l}0.048^{* * * *} \\
(2.32)\end{array}$ & $\begin{array}{l}0.058^{* *} \\
(2.18)\end{array}$ & $\begin{array}{l}0.140^{* * * *} \\
(4.29)\end{array}$ & $\begin{array}{l}0.174 * * * \\
(3.37)\end{array}$ \\
\hline$\triangle E X G$ & $\begin{array}{l}0.290^{* * * *} \\
(8.60)\end{array}$ & $\begin{array}{l}0.314^{* * *} \\
(7.27)\end{array}$ & $\begin{array}{l}0.029^{*} \\
(1.83)\end{array}$ & $\begin{array}{l}0.032 * * \\
(2.02)\end{array}$ & $\begin{array}{l}0.315^{* * *} \\
(12.99)\end{array}$ & $\begin{array}{l}0.339^{* * * *} \\
(9.43)\end{array}$ \\
\hline$\Delta(Y G A P)$ & -- & $\begin{array}{l}0.369 * * * \\
(4.95)\end{array}$ & -- & $\begin{array}{l}0.248 * * * \\
(2.55)\end{array}$ & -- & $\begin{array}{l}0.374 * * * \\
(4.88)\end{array}$ \\
\hline Wald test: $\chi^{2}(n)$ & $4450[0.000]$ & $860.0[0.000]$ & $1310[0.000]$ & $2513[0.000]$ & $9773[0.000]$ & 1209 [0.000] \\
\hline No. of observations & 433 & 441 & 117 & 118 & 316 & 323 \\
\hline $\begin{array}{l}\text { Arellano-Bond tests: } \\
\text { [order1, order 2] }\end{array}$ & {$[0.02,0.65]$} & {$[0.02,0.77]$} & {$[0.05,0.91]$} & {$[0.05,0.10]$} & {$[0.02,0.62]$} & {$[0.03,0.89]$} \\
\hline
\end{tabular}

Notes: This table shows the results of regression model (5) for the pooled sample, five advanced (ADV), and 15 emerging and developing (EMD) countries in Asia for the 1980-2008 period using the Arellano-Bond (1991) GMM method. The dependent variable is CPI inflation $(P H I)$. Exchange rate growth $(E X G)$ and the output gap $(Y G A P)$ are treated as endogenous. The $z$-ratios in parentheses are based on standard errors robust to heteroscedasticity. Significance at the one, five, and ten percent level is given by ***,**, and *, respectively. Wald test statics follow $\chi^{2}(n)$ distribution, where $n$ is the number of regressors except the constant term (with $p$ values in square brackets). The statistics for the Arellano-Bond tests are based on the null hypothesis of no autocorrelation of order 1 and 2 (with $p$-values in square brackets).

The cross-country-augmented Phillips curve incorporates purchasing power parity and monetary gaps in an expectation-augmented Phillips curve. Inflation responds to past inflation (with backward-looking expectations) and positively to excess demand pressure measured by the output gap. As implied by purchasing power parity, world inflation and possible exchange rate depreciations will positively feed into domestic inflation. Accounting for possible feedback effects from inflation on monetary gaps, exchange rate depreciation, and the output gap, we treat $R G A P, E X G$, and $Y G A P$ as endogenous regressors.

Table 3 shows that the effects on inflation of tighter monetary policy are significantly negative and persistent for the EMD Asia and pooled sample. Inflation dynamics entail substantial persistence as indicated by coefficients on lagged dependent for all groups. For the EMD Asia, column (a) regressions suggest that a one-percent-point increase in $R G A P$ 
results in a decrease in inflation on average by 0.91 and 0.75 percent points, respectively, in the short run and long run. As implied by purchasing power parity, world inflation and exchange rate depreciations result in higher domestic inflation, more strongly for the EMD Asia than for the ADV Asia. The pass-through effects of exchange rates on inflation is estimated much larger for the EMD Asia: in column (a) regressions, a one-percent-point increase in exchange rate depreciation raises inflation in the short run (long run) on average by $0.34(0.45)$ percent point for the EMD Asia, and merely by $0.05(0.08)$ percent point for the ADV Asia. Column (b) regressions indicate that the output gap has significantly positive impacts on inflation for all groups. Taken together, demand pressures from monetary policy and the output gap as well as external factors matter for the determination of inflation in Asia.

\section{How Did Monetary Gaps Affect Saving, Investment, And Net Saving Rates?}

We consider the effects of monetary gaps and financial factors on saving, investment, and net saving rates, in addition to output growth and demographic factors. Inter-temporal substitutions imply that an increase in the real interest rate, given the level of income, raises savings and reduces investment. Hence, tighter monetary policy with higher real rates promotes savings and reduces output. If consumption does not keep up with temporary changes in income (the permanent income hypothesis), however, tighter policy may dampen or even reduce savings, offsetting the positive effect of inter-temporal substitution on savings. While tighter monetary policy reduces investment and output, the sign of its impact on investment rates will depend on the relative strength of its impacts on output and investment.

Financial globalization is likely to promote saving and investment rates facilitated by the increased availability of saving instruments and external flows of funding for investment. The effect of financial globalization on net saving rates depends on its relative strength of impacts on saving and investment rates. Non-sterilized reserves lead to an expansion of domestic liquidity and thus do not necessarily constrain investment. In contrast, sterilized reserves do not lead to an expansion of domestic liquidity, while serving as a sovereign liquidity buffer. Hence, to the extent that reserve accumulation is sterilized, it may be associated with lower investment in physical capital.

Existing studies suggest that output growth and demography affect saving and investment rates (for example, IMF 2005; Bosworth and Chodorow-Reich, 2007; and Cooper, 2008). Output growth can promote saving (the permanent income hypothesis) and investment rates (the accelerator principle). Demography will also affect saving and investment rates since individuals save while they work to finance consumption after their retirement. The demographic structure of a country's population can be captured by the youth- and ageddependency ratios. An increase in youth dependency requires more consumption to support young people and consequently reduces savings, and induces an expectation for future 
substitution of labor for capital, reducing investment. ${ }^{10}$ Aged dependency is positively associated with consumption as old people dispose their income for consumption with less need for savings (income effects). At the same time, aging economy may substitute capital for labor to compensate the productivity loss owing to aging population (substitution effects) to the extent that there is room for enhancing productivity through incremental capital.

In line with standard specifications in empirical studies on saving and investment rates, we employ a ratio specification, normalizing a dependent variable by output (GDP). For country $i$ at time $t$, saving rates are explained by

$$
\left(\frac{S}{Y}\right)_{i, t}=b_{i}^{S}+b_{Y G}^{S} Y G_{i, t}+b_{R G}^{s} R G A P_{i, t}+b_{G L}^{s} G L O B_{i, t}+b_{Y D}^{s} Y D E P_{i, t}+b_{A D}^{s} A D E P_{i, t}+v_{i, t}^{s},
$$

where $(S / Y)_{i, t}$ is the savings to output ratio, $b_{i}^{S}$ is a fixed-country effect, $G L O B_{i, t}$ is the $\log$ of the country-specific globalization measure, $Y D E P_{i, t}$ is youth dependency, $A D E P_{i, t}$ is aged dependency, and $v_{j, t}^{S}$ an error term. Similarly, investment rates are explained by

$$
\begin{aligned}
\left(\frac{I}{Y}\right)_{i, t}= & b_{i}^{I}+b_{Y G}^{I} Y G_{i, t}+b_{R G}^{I} R G A P_{i, t}+b_{G L}^{I} G L O B_{i, t}+b_{I R}^{I}\left(\frac{I R}{Y}\right)_{i, t} \\
& +b_{Y D}^{I} Y D E P_{i, t}+b_{A D}^{I} A D E P_{i, t}+v_{i, t}^{I},
\end{aligned}
$$

where $(I / Y)_{i, t}$ is the investment to output ratio, $(I R / Y)_{i, t}$ is the international reserves to output ratio, and $v_{j, t}^{I}$ an error term. Investment rate equation (7) includes the international reserves to output ratio to account for the effect of reserve holdings on domestic investment.

We also consider a regression model for net saving rates (NS) — saving rates minus investment rates - equivalent to the current account balance to output ratio. Incorporating the aforementioned determinants of saving and investment rates, we explain net saving rates for firm $j$ at time $t$ as follows:

$$
\begin{aligned}
\left(\frac{N S}{Y}\right)_{i, t}= & b_{i}^{N S}+b_{Y G}^{N S} Y G_{i, t}+b_{R G}^{N S} R G A P_{i, t}+b_{G L}^{N S} G L O B_{i, t}+b_{I R}^{N S}\left(\frac{I R}{Y}\right)_{i, t} \\
& +b_{Y D}^{N S} Y D E P_{i, t}+b_{A D}^{N S} A D E P_{i, t}+v_{i, t}^{N S},
\end{aligned}
$$

where $N S_{i, t} / Y_{i, t}$ is the net savings to output ratio, and $v_{j, t}^{N S}$ is an error term.

To account for the possible endogeneity of monetary gaps, output growth, and the reserves to GDP ratio in regressions (6)-(8), we use the instrumental variables (IV) method. $R G A P$ should be treated as endogenous, especially to account for the possible causality from

\footnotetext{
${ }^{10}$ In contrast, Cooper (2008) notes that lower birth rates (lower youth dependency) tend to reduce investment, despite capital-labor substitution, because of less demand for schools and housing and thus less new capital.
} 
Figure 6: Monetary Gaps and Net Saving Rates

A. ADV Asia

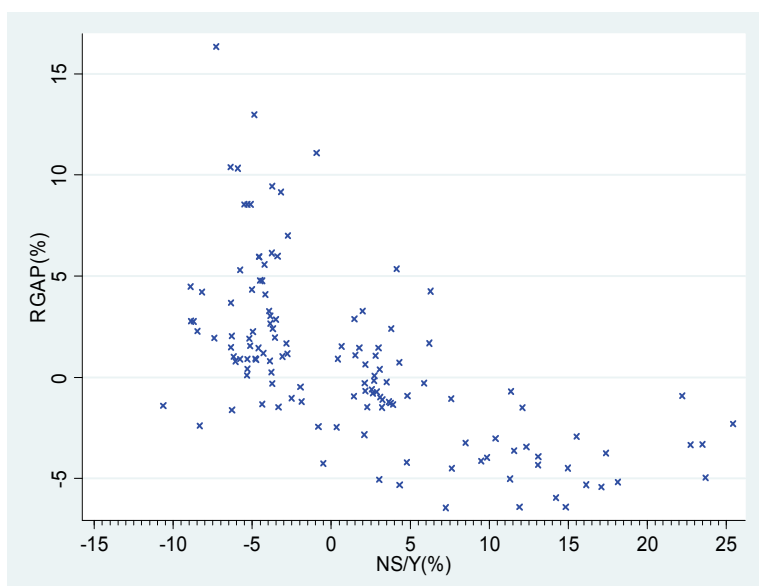

B. EMD Asia

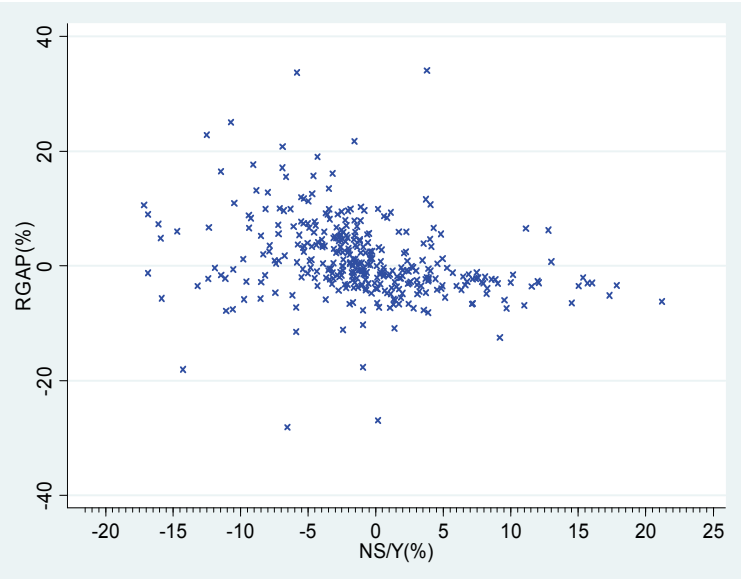

Note: This figure shows monetary gaps $(R G A P)$ and net saving rates $(N S / Y)$ for advanced (ADV) and emerging and developing (EMD) countries in Asia.

the current account balance to monetary gaps. Figure 6 shows that a negative correlation between $R G A P$ and net saving rates is much more apparent for the ADV Asia than for the EMD Asia (correlation is -0.75 and -0.15 , respectively). A negative correlation could reflect lower interest rates due to the excess liquidity from the current account surplus. The output growth and reserve-to-GDP ratio may also respond endogenously to investment, saving, or net saving rates (for example, investment stimulates output growth and reduces foreign assets including reserves). A first-stage regression showed that the instruments were highly correlated with the endogenous variable. The Hansen test for overidentification suggests that the regression model is correctly specified and the instruments are valid. ${ }^{11}$ Statistical inferences about coefficient estimates are based on heteroscedasticity and autocorrelation consistent standard errors.

Table 4 summarizes the estimated results of regressions (6)-(8), providing evidence on the negative effects of tighter monetary policy on the current account balance. ${ }^{12}$ The effect of tighter policy on saving rates is significant for the pooled and EMD Asia groups but insignificant for the ADV Asia. Tighter policy has stronger positive effects on investment rates than on saving rates for all country groups, although less significant for the ADV Asia. The estimated positive effects on investment rates reflect that tighter policy reduces output proportionately more than investment, increasing the investment-output ratio. This finding is

\footnotetext{
${ }^{11}$ The Stock and Yogo (2005) test supports the validity of our instruments: the test rejected the null hypothesis of weak instruments at least at the 30 percent level for any set of the endogenous variables instrumented.

${ }^{12} \mathrm{We}$ also estimated regressions with random effects to utilize both the cross-sectional and time-series information in the data and found qualitatively the same results. The validity of our models with random effects was supported by the Hausman test results.
} 


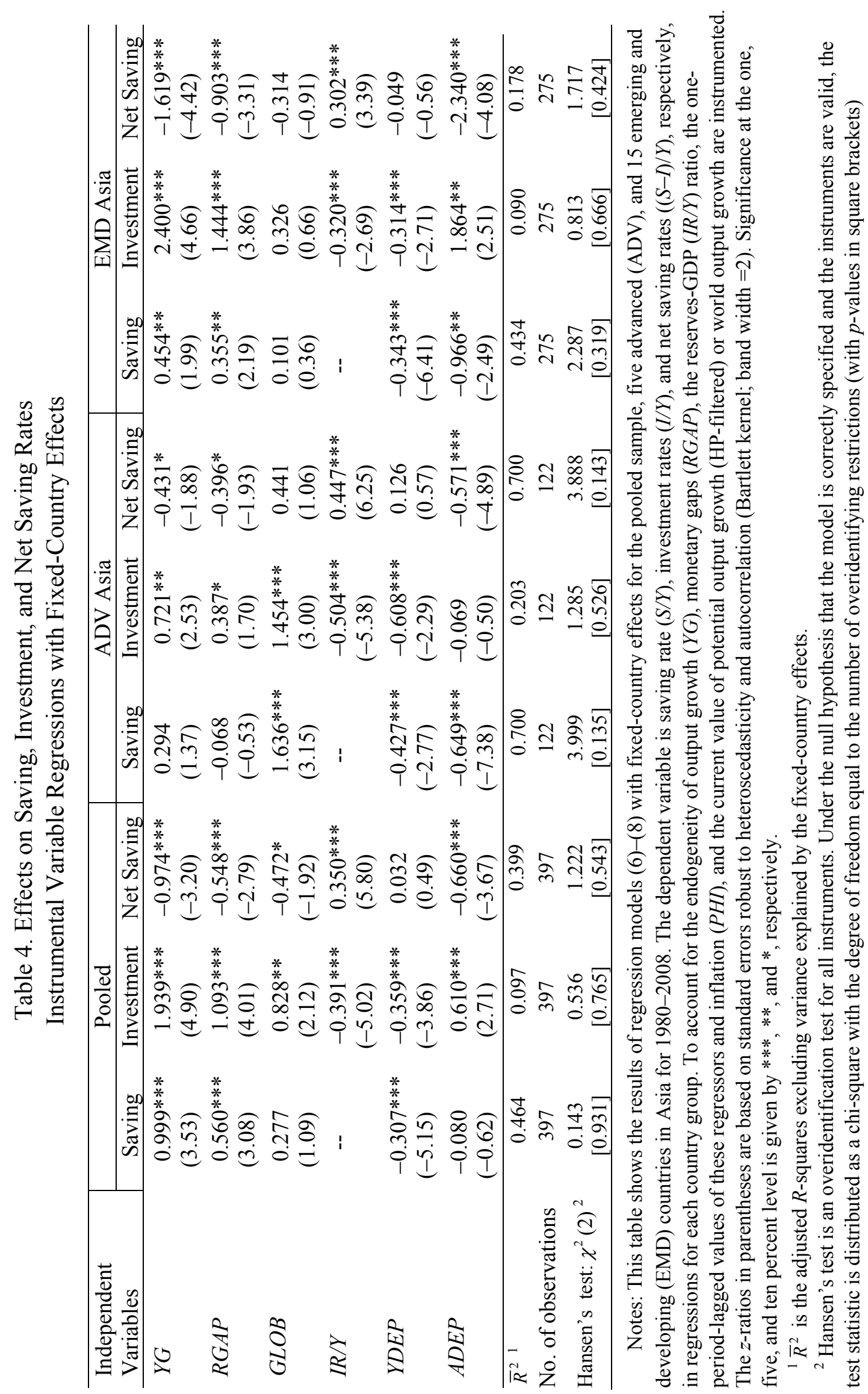


consistent with the strong effect of $R G A P$ on output growth (Table 2) and the relatively weak or insignificant effects of $R G A P$ on investment growth (not reported). The estimated effects of tighter policy on net saving rates squares well the difference between those on saving and investment rates. The relatively small effect on saving rates may reflect that tighter policy increases savings through inter-temporal substitution but dampens them as consumption keeps up with permanent income. The effect of $R G A P$ on net saving rates, after controlling for the reverse causality, proves to be weak for advanced countries but strong for the EMD Asia. Our estimated results imply that a one-percent-point increase in $R G A P$ leads to a decrease in net savings, on average, about 0.9 percent of output when the current account balance equals zero for the ADV Asia. ${ }^{13}$

Other noteworthy findings are as follows. First, faster output growth boosts both saving and investment rates for all country groups, although insignificant on saving rates for the ADV Asia. Output growth has larger effects on investment rates than on saving rates, rendering its effects on net saving rates negative - much more strongly for the EMD than the ADV Asia. Second, a significant negative coefficient on the reserves-output ratio suggest that the negative effect of possible sterilized reserve holdings outweighs positive or neutral effects of reserve holdings on domestic investment for all Asian country groups. Since reserve holdings do not significantly affect savings (and thus excluded in saving rate regressions), the adverse effect of reserve holdings on investment implies a positive effect of reserve holdings on net saving rates. The positive effect of reserve holdings on net saving rates is strongly pronounced for all Asian country groups. Third, financial integration tends to stimulate savings and concomitantly investment for the ADV Asia but not the EMD Asia. This finding may suggest that advanced Asian countries benefited more from even-handed exposures to international financial assets and debt instruments through financial integration than emerging market and developing Asia did.

Finally, as expected, demographic factors matter for saving and investment rates. Youth dependency has negative effects of similar magnitudes on saving and investment rates, resulting in little or insignificant effects on net saving rates for all country groups. Aged dependency has negative effects on net saving rates for all country groups. It has differential effects between saving and investment and across country groups: a significant negative effect on saving rates for both country groups; and a significant positive effect on investment rates for the EMD Asia but an insignificant effect for the ADV Asia. The positive effect on investment rates of aged dependency for the EMD Asia may reflect that countries, given room for enhancing productivity through incremental capital, tend to increase investment to substitute capital for labor in the face of declining labor productivity with aging population.

\footnotetext{
${ }^{13}$ We can calculate the effect of $R G A P$ on the level of net savings (NS) using Tables 2 and 4 , along with comparative statics. $\partial N S$ / $\partial R G A P=a Y+b N S$, where $a=\partial(N S / Y) / \partial R G A P$, which is the coefficient of $R G A P$ in Table 4 divided by 100; and $b=(1 / Y)(\partial Y / \partial R G A P)$, which equals the coefficient of $R G A P$ in Table 2 divided by 100 .
} 
Our inferences from regressions (6)-(8) remain largely intact for a number of robustness checks including the following dimensions.

- We checked if the positive effect of $R G A P$ on investment rates reflects the boosting effect on investment from higher real rates associated with financial liberalization. ${ }^{14}$ To do this, we ran the regressions excluding the observations with negative real rates for three consecutive years as a proxy for financial repression era.

- We included the fiscal gap, measured by the saving-investment gap of the government sector, as an additional regressor. The $z$-ratio of $R G A P$ coefficient is slightly reduced, possibly owing to a negative correlation between the fiscal gap and $R G A P$ through the link between interest rates and debt service. Ricardian equivalence (RE) and crowding-out (CO) effects, along with the accounting relationship that net saving rates comprise saving-investment gaps in the private and government sectors, determine the effects of the fiscal gap in the regressions. ${ }^{15}$ For the pooled sample and EMD Asia, the fiscal gap had a positive effect (around 0.3) on saving rates, a strong positive effect on investment rates (somewhat greater than 1), and a weak negative effect on net saving rates $(-0.3$ for the pooled sample and -0.6 for the EMD Asia). For the ADV Asia, the fiscal gap had somewhat larger positive effects on saving rates than on investment rates (similar RE effects and much smaller CO effects, compared to the EMD Asia), resulting in a weak positive effect on net saving rates.

- We included dummies for exchange regimes as additional regressors. As in Choi, Sharma, and Strömqvist (2009), exchange regimes were divided into a fixed, intermediate, and flexible regime, using the de facto regime classification by Reinhart and Rogoff (2004a) and Ilzetzki, Reinhart, and Rogoff (2008). Regime dummies were statistically insignificant in the existence of fixed-country effects.

\footnotetext{
${ }^{14}$ The McKinnon-Shaw view (see, for example, Agrawal, 2004) suggests that, in the countries (or periods) under financial repressions, higher interest rates with financial liberalization lead to higher bank deposits and more bank loans, promoting investment.

${ }^{15}$ In the absence of RE and CO effects (for discussions on RE and CO effects, see Choi and Devereux, 2006), the fiscal gap has a one-to-one contribution to net saving rates through the accounting relationship. However, a (partial) RE effect reduces the pass-through of the fiscal gap to saving rates through implications for future tax liabilities, and a $\mathrm{CO}$ effect increases the fiscal gap impact on investment rates through long-term financing conditions for private investment. Hence, the fiscal gap increases, but less than proportionately, saving rates and increases investment rates, affecting ambiguously net saving rates.
} 


\section{CONCLUding ReMARKS}

This paper provides evidence on the international transmission of monetary policy, through which the global monetary gap propagates into domestic output growth, inflation, and net saving rates. Our cross-county panel regression results suggest that the inter-linkage between the global and domestic monetary gaps is pronounced for the EMD (emerging and

developing) Asia, which has substantively accommodated global monetary conditions under financial integration. Persistent negative monetary gaps, reflecting expansionary global monetary policy, have not only increased output growth and inflation but also the current account surplus (net saving rate) for the EMD Asia.

Other noteworthy findings are as follows. First, output growth is negatively associated with inflation for the EMD Asia and the reserves-GDP ratio for the EMD and ADV (advanced) Asia. Second, inflation is positively associated with world inflation, exchange rate depreciation, and the output gap, consistent with the cross-country-augmented Phillips curve. Third, international reserve holdings tend to reduce domestic investment for all Asian country groups, possibly reflecting excess accumulation of reserves at the expense of lower investment. Financial integration tends to stimulate savings and concomitantly investment for the ADV Asia but not for the EMD Asia. Lastly, this paper provides evidence that monetary gaps contribute to higher net saving rates, although it does not go into the responses of exports and imports to monetary gaps.

Our findings lend support to the existence of a feedback loop between the global monetary gap and global imbalances. First, the negative link between the global monetary gap and Asia's net saving rates suggests that global monetary expansions are partly responsible for the large current account surplus in Asia. Second, policy inter-linkages reflect that interventions, rather than exchange rate adjustments, have been the first line of defense in dealing with capital flows. The resulting build-up of reserves has funneled vast quantities of dollars into international capital markets and induced low returns on U.S. government securities (the uphill capital flows). Third, the large capital reflows to global financial markets in turn feed into domestic monetary gaps, completing the feedback loop. Hence, global policy coordination for rebalancing would require the realignment of the platform of global and domestic monetary policies. Unwinding the global monetary gap will help reduce global imbalances. 


\section{References}

Agrawal, Pradeep, 2004, "Interest Rates and Investment in East Asia: An Empirical Evaluation of Various Financial Liberalisation Hypotheses," Journal of Development Studies, Vol. 40 (February), pp. 142-73.

Astley, Mark, Julia Giese, Michael Hume, and Chris Kubelec, 2009, "Global Imbalances and the Financial Crisis," Bank of England Quarterly Bulletin, Vol. 49 (3rd Quarter), pp. 178-90.

Arellano, Manuel, and Stephen Bond, 1991, "Some Tests of Specification for Panel Data: Monte Carlo Evidence and an Application to Employment Equations," Review of Economic Studies, Vol. 58 (April), pp. 277-97.

Bernanke, Ben S., 2005, "Remarks by Governor Ben S. Bernanke: The Global Saving Glut and the U.S. Current Account Deficit." The Sandridge Lecture, Virginia Association of Economists, Richmond, VA (March 10). URL: http://www.federalreserve.gov/boarddocs/speeches/2005/20050414/default.htm

Bosworth, Barry, and Gabriel Chodorow-Reich, 2007, "Saving and Demographic Change: The Global Dimension," Working Papers 2007-02, Center for Retirement Research at Boston College.

Bosworth, Barry P., and Susan M. Collins, 1999, "Capital Flows to Developing Economies: Implications for Saving and Investment," Brookings Papers on Economic Activity, (Issue 1), pp. 143-69.

Blanchard, Olivier, and Gian Maria Milesi-Ferretti, 2009, "Global Imbalances: In Midstream?” IMF Staff Position Note 09/29 (Washington: International Monetary Fund).

Caballero, Ricardo, Emmanuel Farhi, and Pierre-Olivier Gourinchas, 2008, “An Equilibrium Model of 'Global Imbalances' and Low Interest Rates," American Economic Review, Vol. 98 (March), pp. 358-93.

Calvo, Guillermo A., Leonardo Leiderman, Carmen M. Reinhart, 1996, "Inflows of Capital to Developing Countries in the 1990s," Journal of Economic Perspectives, Vol. 10 (Spring), pp. 123-39.

Calvo, Guillermo A., Leonardo Leiderman, Carmen M. Reinhart, 1994, “The Capital Inflows Problem: Concepts and Issues," Contemporary Economic Policy, Vol. 12 (3), pp. 54-66.

Carmichael, Jeffrey, and Peter W. Stebbing, 1983, "Fisher's Paradox and the Theory of Interest," American Economic Review 73 (September), pp. 619-30.

Choi, Woon Gyu, 2002, "Inverted Fisher Hypothesis: Inflation Forecastability and Asset Substitution," IMF Staff Papers, Vol. 49, No. 2, pp. 212-41. 
Choi, Woon Gyu, and David Cook, 2004, "Liability Dollarization and the Bank Balance Sheet Channel," Journal of International Economics, Vol. 64 (December), pp. 247-75.

Choi, Woon Gyu, and Michael Devereux, 2006, “Asymmetric Effects of Government Spending: Does the Level of Real Interest Rates Matter?” IMF Staff Papers, Vol. 53 (September), pp.147-81.

Choi, Woon Gyu, Sunil Sharma, and Maria Strömqvist, 2009, "Net Capital Flows, Financial Integration, and International Reserve Holdings: The Recent Experience of Emerging Markets and Advanced Economies," IMF Staff Papers, Vol. 56 (August), pp. 516-40.

Clarida, Richard, Jordi Galí, and Mark Gertler, 2002, "A Simple Framework for International Monetary Policy Analysis,” Journal of Monetary Economics, Vol. 49 (July), pp. 879-904.

Clarida, Richard, Jordi Galí, and Mark Gertler, 2001, "Optimal Monetary Policy in Open versus Closed Economies: An Integrated Approach," American Economic Review, Vol. 91 (May), pp. 248-52.

Cooley, Tomas F., and Gary D. Hansen, 1989, "The Inflation Tax in a Real Business Cycle Model," American Economic Review, Vol. 79 (September), pp. 733-47.

Cooper, Richard N, 2008, “Global Imbalances: Globalization, Demography, and Sustainability," Journal of Economic Perspectives, Vol. 22 (Summer), pp. 93-112.

Cova, Pietro, Massimiliano Pisani, and Alessandro Rebucci, 2009, "Global Imbalances: The Role of Emerging Asia," Review of International Economics, Vol. 17 (September), pp. 716-33.

Dooley, Michael P., Folkerts-Landau, David, and Peter Garber, 2004, "The Revived Bretton Woods System: The Effects of Periphery Intervention and Reserve Management on Interest Rates and Exchange Rates in Center Countries,” NBER Working Paper 10332 (Cambridge: National Bureau of Economic Research).

Durdu, Bora, Enrique Mendoza, and Marco Terrones, 2009, "Precautionary Demand for Foreign Assets in Sudden Stop Economies: An Assessment of the New Mercantilism," Journal of Development Economics, Vol. 89 (July), pp. 194-209.

Elekdag, Selim, and Ivan Tchakarov, 2007, "Balance Sheets, Exchange Rate Policy, and Welfare," Journal of Economic Dynamics and Control, Vol. 31, pp. 3986-4015.

Ilzetzki, Ethan O., Reinhart, Carmen M., and Kenneth S. Rogoff, 2008, "Exchange Rate Arrangements into the 21st Century: Will the Anchor Currency Hold?" Mimeograph.

International Monetary Fund, 2010, "Global Liquidity Expansion: Effects on "Receiving" Economics and Policy Response Options,” Global Financial Stability Report, (April), Chapter 2 (Washington: International Monetary Fund). 
International Monetary Fund, 2009, "Lessons for Monetary Policy from Asset Price Fluctuations," Chapter 3 in World Economic Outlook, October 2009: Sustaining the Recovery, World Economic and Financial Surveys, pp. 93-120 (Washington: International Monetary Fund).

International Monetary Fund, 2005, "Global Imbalances: A Saving and Investment Perspective," Chapter 2 in World Economic Outlook 2005, (September), pp. 91-124 (Washington: International Monetary Fund).

Lane, Philip R., and Gian Maria Milesi-Ferretti, 2007, "The External Wealth of Nations Mark II: Revised and Extended Estimates of Foreign Assets and Liabilities, 1970-2004," Journal of International Economics, Vol. 73 (November), pp. 223-50.

Lucas, Robert, 1990, “Why Doesn't Capital Flow from Rich to Poor Countries?” American Economic Review, Vol. 80 (May), pp. 92-6.

Mendoza, Enrique G., Vincenzo Quadrini, Jose-Victor Rios-Rull, 2009, "Financial Integration, Financial Development, and Global Imbalances," Journal of Political Economy, Vol. 117 (June), pp. 371-416.

Khan, Mohsin S., and Abdelhak S. Senhadji, 2001, "Threshold Effects in the Relationship between Inflation and Growth," IMF Staff Papers, Vol. 48, pp. 1-21.

Obstfeld, Maurice, and Kenneth Rogoff, 2009, "Global Imbalances and the Financial Crisis: Products of Common Causes,” C.E.P.R. Discussion Papers, No 7606.

Ostry, Jonathan D., Atish R. Ghosh, Karl Habermeier, Marcos Chamon, Mahvash S. Qureshi, and Dennis B.S. Reinhardt, 2010, "Capital Inflows: The Role of Controls," Staff Position Note 10/04 (Washington D.C.: International Monetary Fund).

Reinhart, Carmen M., and Kenneth S. Rogoff, 2004a, "The Modern History of Exchange Rate Arrangements: A Reinterpretation," Quarterly Journal of Economics, Vol. 119 (February), pp. 1-48.

Reinhart, Carmen M., and Kenneth S. Rogoff, 2004b, "Serial Default and the "Paradox" of Rich-to-Poor Capital Flows," American Economic Review, Vol. 94 (May), pp. 53-8.

Stock, James H., and Yogo, Motohiro, 2005, "Testing for Weak Instruments in Linear IV Regression, Identification and Inference for Econometric Models, Essays in Honor of Thomas Rothenberg, pp. 80-108 (Cambridge and New York: Cambridge University Press).

Trehan, Bharat, and Tao Wu, 2007, “Time-varying Equilibrium Real Rates and Monetary Policy Analysis," Journal of Economic Dynamics \& Control, Vol. 31, pp. 1584-1609. 


\section{Appendix A: Country Group List}

Asian 20 countries are split into two country groups. The emerging market and developing (EMD) Asia group (15) comprises Bangladesh, Cambodia, China, India, Indonesia, Korea, Laos, Malaysia, Myanmar, Pakistan, Philippines, Sri Lanka, Taiwan, Thailand, and Vietnam. The advanced (ADV) Asia group (5) comprises Australia, Hong Kong SAR, Japan, New Zealand, and Singapore. Our advanced country group includes Hong Kong SAR and Singapore because their per capita incomes have been well above the sample mean of the advanced countries for at least the last 10 years.

\section{Appendix B: Descriptive Statistics of Key Variables}

\begin{tabular}{lcccccc}
\hline \multicolumn{1}{c}{ Variable } & Units & $\mathrm{N}$ & Mean & Std & Min & Max \\
\cline { 1 - 6 } \multicolumn{2}{c}{ Advanced countries (ADV) / Emerging market and developing countries (EMD) } & \\
RGAP & $\%$ & $131 / 357$ & $0.72 / 1.00$ & $4.21 / 6.88$ & $-6.44 /-28.1$ & $16.3 / 34.1$ \\
GDP growth & $\%$ & $140 / 420$ & $3.93 / 6.03$ & $3.32 / 3.87$ & $-6.03 /-13.1$ & $13.4 / 24.1$ \\
CPI inflation & $\%$ & $140 / 420$ & $3.54 / 14.3$ & $3.98 / 36.4$ & $-3.96 /-43.6$ & $16.2 / 487$ \\
Output gap & $\%$ & $145 / 435$ & $-0.01 / 0.04$ & $2.99 / 3.88$ & $-10.0 /-14.3$ & $6.13 / 16.3$ \\
Saving rates & $\%$ & $145 / 379$ & $27.2 / 23.7$ & $10.2 / 10.3$ & $8.73 /-14.2$ & $52.8 / 52.4$ \\
Investment rates & $\%$ & $145 / 379$ & $25.7 / 24.8$ & $5.96 / 8.77$ & $13.6 / 6.13$ & $44.8 / 51.5$ \\
Net saving rates & $\%$ & $145 / 425$ & $1.49 /-1.63$ & $7.91 / 5.99$ & $-13.4 /-21.9$ & $25.4 / 21.2$ \\
Net capital flows/GDP & $\%$ & $145 / 435$ & $0.15 / 2.99$ & $6.86 / 5.39$ & $-21.6 /-18.3$ & $15.6 / 39.7$ \\
Exchange rate growth & $\%$ & $140 / 404$ & $0.28 / 11.5$ & $8.56 / 51.8$ & $-29.4 /-21.6$ & $25.6 / 675$ \\
Reserves/GDP & $\%$ & $135 / 415$ & $29.1 / 13.1$ & $33.1 / 14.0$ & $1.07 / 0.46$ & $103 / 74.5$ \\
Aged dependency & $\%$ & $145 / 425$ & $15.7 / 7.59$ & $5.22 / 1.86$ & $6.91 / 4.96$ & $32.9 / 14.5$ \\
Youth dependency & $\%$ & $145 / 425$ & $30.5 / 58.7$ & $5.57 / 17.2$ & $16.8 / 23.9$ & $43.1 / 91.4$ \\
GLOB (equity) & & $136 / 315$ & $2.87 / 0.24$ & $1.37 / 2.23$ & $-4.10 /-5.84$ & $5.98 / 4.37$ \\
Fiscal gap & $\%$ & $145 / 423$ & $0.64 /-3.22$ & $4.53 / 3.83$ & $-8.21 /-17.42$ & $14.3 / 8.69$ \\
\hline
\end{tabular}

Notes: This table shows descriptive statistics of key variables for 1980-2008 for the two country groups (ADV/EMD) in Appendix A. Columns 3-7 show statistics for ADV/EMD in parallel. Reserves are defined as gross reserves net of gold in U.S. dollars (USD). The output gap is measured by $100 \times \log ($ real GDP/potential GDP), where the potential GDP is the HP stochastic trend of real GDP. Investment rates are measured by the percentage ratio of total (real) investment to (real) GDP. Net saving rates are defined as the percentage ratio of the current account balance to GDP. Saving rates are measured by the sum of investment and net savings rates. A positive (negative) exchange rate growth means a depreciation (appreciation) of a country's currency vis-àvis U.S. dollars (average of period data). The aged dependency ratio is the percentage ratio of 65 -and-above population to total population; and the youth dependency ratio is the percentage ratio of under- 15 population to total population. GLOB (equity) is the logarithm of the two-year average of the percentage ratio of the sum of the portfolio equity assets \& liabilities and the stock of foreign direct investment assets \& liabilities to GDP. The fiscal gap is measured by the percentage ratio of the government sector saving-investment gap to GDP. 